\title{
Tables of Trigonometric Functions in Non-Sexagesimal Arguments
}

Excluding the ordinary tables of trigonometric functions in sexagesimal arguments the two principal groups of such tables are those with arguments in A. Radians, - tables of this type have been already listed in RMT 81; and B. Grades. But we shall also consider tables of the trigonometric functions with arguments in C. Mils; D1. Gones; D2. Cirs; and E. Time.

B. Grades. The first stage in the evolution of the centesimal division of the quadrant was by the division of each sexagesimal degree into 100 minutes and each of these minutes into 100 seconds. This was conceived already about 1450 by Theodericus Ruffi, in a Latin codex in Munich. ${ }^{1}$ The centesimal division of the degree was also presented by Vieta in his Calendarij Gregoriani, 1600 , p. "29"(Opera Mathematica, 1646, p. 487). It was this source which suggested to Henry Briggs the choice of every hundredth of a degree as the unit in the preparation of his wonderful "sine canon"; 2 see RMT 79.

Late in the eighteenth century the centesimal division of the quadrant was definitely in the thought of scholars then in Berlin and especially of JoHANN CARL Schulze (1749-1790), author of Neue und erweiterte Sammlung logarithmischer, trigonometrischer und anderer zum Gebrauch der Mathematik unentbehrlicher Tafeln [also French t.p.], Berlin, 2v., 1778. He had studied under J. H. Lambert (1728-1778) and became a member of the Academy of Sciences at Berlin, in which Lagrange (following Euler) was director of its mathematical section for a score of years before he moved to Paris in 1787. In the preface of the first volume of his Tafeln, and also in his work of 1783 (referred to by Mehmke in his splendidly documented report ${ }^{3}$ ) Schulze appears to have made ready for the press a manuscript of a seven-place table of natural trigonometric functions and of their logarithms for every thousandth of a sexagesimal degree. Since Lagrange expressed the opinion that a table for arguments involving the centesimal division of the quadrant (into grades) would be more desirable, Schulze gave up the plan of publishing his table and promoted the calculation of the type suggested by Lagrange. A substantial table of this type did finally appear in Berlin, nearly a decade after Schulze's death. This was

(1). Johann Philipp Hobert (1759-1826) and Christian Ludwig Ideler (1766-1846), Neue trigonometrische Tafeln für die Decimaleintheilung des Quadranten, Berlin, 1799, lxxii, 353 p. $11.7 \times 20.5 \mathrm{~cm}$.

On p. 1-309 is a table of sines, cosines, tangents, cotangents, and of their logarithms for every $10^{\prime \prime}$ to $3^{o}$, and then for each $1^{\prime}$ to $50^{g}$, to $7 \mathrm{D}$, with differences. On p. 313-315 are tables to $10 \mathrm{D}$, with differences, of natural sines and tangents for $0^{\prime \prime}\left(1^{\prime \prime}\right) 1^{\prime}\left(1^{\prime}\right) 1^{g}$. Of this volume Delambre has well written, "Cet ouvrage m'a paru d'une correction et d'une exactitude rares." In (2). Astronomisches Jahrbuch für das Jahr 1798, Berlin, 1795, J. E. BoDE published an unimportant table for these same 8 functions, for each half grade $\left(=27^{\prime}\right)$ to 7D. An earlier table in the centesimal division served Hobert and Ideler as a valuable check on their computation. But before considering this we shall refer to another matter which contributed to the persistence of centesimal tables to the present day. 
I refer to the movement which culminated during the decade of the French revolution in the establishment of the Metric System. In 1799 a law was passed definitely fixing the unit of length, a meter, as one ten millionth of the quadrant of the terrestrial meridian through Paris; the unit of volume, a liter, as equivalent to a cube of edge one tenth of a meter; the unit of weight, a gram, as equivalent to a cubic centimeter of distilled water at the maximum density, $4^{\circ} \mathrm{C}$, weighed in vacuo. This new system became compulsory in 1801 . Delambre, Lagrange, Laplace, Legendre and Monge were mathematicians among members of the Commission establishing these units. In 1920 the Metric System was the only legal one in 35 countries, and its use was also allowed in 11 others, including Great Britain and United States.

On representations of the mathematician L. N. M. Carnot, and others, the French Government decided in 1784 that new tables of the sines, tangents, etc., and their logarithms, should be constructed. The execution of this task was in 1792 put in the hands of Gaspard Clair François Marie Riche DE Prony (1755-1839), then director of the Bureau du Cadastre. Hence the resulting tables are referred to as (3). Tables du Cadastre. In order to call special attention to the new French Metric System Riche de Prony was expressly charged "non seulement à composer des tables qui ne laissassent rien à desirer quant à l'exactitude, mais à en faire le monument de calcul le plus vaste et le plus imposant qui eût jamais été exécuté ou même conçu." To carry through the work almost unlimited powers were given to the director in the choice and organization of his collaborators and computers.

These were divided into three groups; the first, consisting of four or five mathematicians (with Legendre as president), was occupied with analytic work and the calculation of fundamental numbers. The second group contained seven or eight skilled computers, working on formulae supplied by the first group, and checking work by the 70 or 80 members of the third group endowed with no great mathematical abilities. In fact they were mainly recruited from among hairdressers whom the abandonment of the wig and powdered hair in men's fashions, had deprived of a livelihood. The work on the tables, which was done wholly in duplicate, by two divisions of the computers, was finished in two or three years. Until recently, at least, one set of the 17 large folio volumes of ms. was in the library of the Paris Observatory, and the other set in the Library of the Institut de France. In each set 8 volumes were devoted to logarithms of numbers to 200,000. For this article it is only the contents of the remaining 9 volumes which are of interest.

There was one volume of natural sines for each centesimal minute in the quadrant, to $25 \mathrm{D}$, with 7 or 8 columns of differences; to be published, to $22 \mathrm{D}$, with 5 columns of differences. Four volumes were devoted to: (a) $\log \sin a$ throughout the quadrant for each tenth of a centesimal minute, to $14 \mathrm{D}$, with 5 columns of differences; (b) $\log \sin a / a$ for $a=[0.00000(0.00001) 0 \% 05000$; 14D], with 5 columns of differences.

And finally, there were four volumes for (a) $\log \tan a$, and (b) $\log \tan a / a$,for the same ranges as for $\log \sin a$, and $\log \sin a / a$.

The mss. of the Institut have also a volume of the first 500 multiples of certain sines and cosines. In the more complete mss. of the Observatory two v. in addition to the $17 \mathrm{v}$., include a 63-page Introduction in Riche de Prony's handwriting, and such subsidiary tables as, (a) the first 26 powers of $\pi / 2$, to 
$28 \mathrm{~S}$; (b) $\log \sin a$, to $14 \mathrm{D}$, with 8 orders of differences, for varying values of $a$ throughout the quadrant.

An arrangement was made for the publication of a stereotype folio volume of these tables, to contain $1200 \mathrm{p}$. exclusive of the introduction. The one hundred plates made seem to have included all the table of natural sines; but financial difficulties prevented the continuation of the undertaking. De Morgan tells us that "a distinguished member of the Board of Longitude, London, was instructed by our Government to propose to the Board of Longitude of Paris to print an abridgement of these tables, at the joint expense of the two countries. $£ 5000$ was named as the sum which our Government was willing to advance for this purpose; but the.proposal was declined." Note the French statement in Nouv. Ann.4 "Il y a eu des négociations à ce sujet avec le gouvernement anglais qui n'aboutirent pas."

The first printed table for the centesimal division of the quadrant was in that remarkable collection of tables of

(4). Jean Francois Callet (1744-1799), Tables Portatives de Logarithmes, first stereotyped ed., Paris, $1795.14 \times 22.2 \mathrm{~cm}$. There have been many editions, even down to 1906.

In this large volume there is one table $(50 \mathrm{p}$.) containing the logarithms of the sine, cosine and tangent, for $\left[0^{\circ}\left(1^{\prime}\right) 50^{\circ} ; 7 \mathrm{D}\right]$, with differences. This is followed by a table $(10 \mathrm{p}$.) of the natural sines and cosines, to $15 \mathrm{D}$, and of their logarithms, to $14 \mathrm{D}$, for every $10^{\prime}$. For the first of these tables

(1). Hobert and Ideler list (l.c., p. 348-349) 375 seventh-place unit errors, and one other error. (5). Borda and Delambre list (p. 120) one error in this table and four in the second; a fifth listed error was not an error in the Brown University copy. All of these errors were already corrected in the (4A). 1821 tirage of Callet's tables.

We come next to an excellent volume issued from "L'Imprimerie de la République."

(5). Tables Trigonométriques Décimales ou Table des Logarithmes des Sinus, Sécants et Tangentes suivant la Division du Quart de Cercle en 100 Degrés, du Degré en 100 Minutes, et de la Minute en 100 Secondes; précédées de la Table des Logarithmes des Nombres . . . et de Plusieurs Tables Subsidiaires, Calculées par JEAN CHARLES BORDA (1733-1799), revues, augmentées et publiées par J. B. J. Delambre. Paris, 1801. $17.5 \times 22.3 \mathrm{~cm}$.

The table in which we are interested is a seven-place logarithm table of all six of the trigonometric functions from $0^{\circ}$ to $3^{\circ}$ for every $10^{\prime \prime}$ (with full proportional parts for every second) and thence for every 1', with full proportional parts for every $10^{\prime \prime}$. Delambre tells us (p. 39) that these were the first tables for the centesimal division of the quadrant that were ever made, since Borda had already finished the manuscript in 1792. He tells us also that Callet (1795) used Borda's manuscript as well as the Tables $d u$ Cadastre in preparing his tables. Since Hobert and Ideler had also used Callet we thus have three tables materially indebted to the Tables $d u$ Cadastres, with which Delambre especially made a detailed comparison of parts common with Borda's manuscript. The tables of Hobert and Ideler, and Borda, are in argument of exactly the same extent, but the former does not give secants nor proportional parts all calculated; on the other hand it does contain values of the natural sines 
and tangents. Delambre, no. (5), states these facts exactly, in contrast to Glaisher whose remark might readily mislead. ${ }^{5}$

We shall next refer to important (6). Manuscripts of EDward SaNG (18051890), author of the notable $A$ New Table of Seven-Place Logarithms of all Numbers from 20000 to 200 000, London, 1871. Of these mss. the Royal Society of Edinburgh is now custodian for the British Nation. ${ }^{6}$ From Henderson I learn that of the mss. in which we are now interested the first was a Canon of Sines to 33D for each two-thousandth part of the quadrant (finished in 1877). There followed (1881) a Canon of Sines to $15 \mathrm{D}$ for each centesimal minute, with first and second interscript differences; and (1888) Logarithmic Sines and Tangents to $15 \mathrm{D}$ for each ten-thousandth of the quadrant.

The following quotation from the abstract written by Sang (Henderson) is not without interest:

For the utilisation of a method of solving Kepler's problem the values of circular segments measured in degrees of surface for each of the 40000 minutes of the circumferences and tables of the true anomalies for each degree in orbits of each degree of ellipticity were computed and laid on the table of the Royal Society of Edinburgh in July 1879. For mean anomalies, etc., it became necessary to calculate a canon of the centesimal division. In Callet's Tables Portatives there is a table to $7 \mathrm{D}$ for every minute and on examination on the page for $31^{\circ}$ there were 23 errors of discrepancy in the differences."

We have already noted that the great (3). Tables $d u$ Cadastre, were never published. In 1888, however, the French Minister of War requested the Service Géographique de l'Armée to prepare two tables, a large eight-place table, to be abridged from Riche de Prony's ms., and a five- (four-) place table for more general use. The first work, prepared by Mm. Villedeuil and L'Hôpital, has the following title:

(7). Tables des Logarithmes a huit Décimales des Nombres entiers de 1 d 120000 et des Sinus et Tangentes de dix Secondes en dix Secondes d'Arc dans le Système de la Division Centésimale du Quadrant, Paris, Imprimerie Nationale, 1891 [viii, 622 p.]. $27.5 \times 34.7 \mathrm{~cm}$. Preface signed by Général Derrécagaix, director of the Service. The large unnumbered pages 225-622 are devoted to a table of logarithms of sines, cosines, tangents, cotangents, to $8 \mathrm{D}$, for every $10^{\prime \prime}$ (semiquadrantal), with p.p. for each second. S and $\mathrm{T}$ are given for every centesimal minute up to $5^{\circ}$.

The second (though first published) work prepared by the Service Géographique de l'Armée had the following title:

(8). Nouvelles Tables de Logarithmes à cinq Décimals pour les Lignes Trigonométriques dans les deux Systèmes de la Division Centésimale et de la Division sexagésimale du Quadrant, et pour les Nombres de 1 à 12000 suivies des mêmes Tables à quatre Décimales et des diverses Tables et formules usuelles. Paris, Imprimerie Nationale, 1889,235 p. $17.3 \times 25.5 \mathrm{~cm}$. Preface by Colonel Derrécagaix, director of the Service Géographiques de l'Armée. On pages 65-164 are given the logarithms of sines, cosecants, tangents, cotangents, secants, and cosines, to $5 \mathrm{D}$, for each 1 , with differences and p.p. Then follow tables, to $5 \mathrm{D}$, of $\mathrm{S}$ and $\mathrm{T}$, for every $2^{\prime}$ in the first $3^{\circ}$. On p. 212-215 are logarithms of sines, cosines, tangents, cotangents, to $4 \mathrm{D}$, for every $10^{\prime}$ in the quadrant; on p. 220-223 is a similar table for the natural functions.

After 1904, students at the École Polytechnique and Ecole Saint-Cyr were 
required to be able to use tables of trigonometric functions with centesimal divisions of the arc. For these schools was published a special edition

(8A). Nouvelles Tables... [as above] pour les Nombres 1 a 12 000. Edition Spéciales a l'usage des Candidats aux Ecoles Polytechnique et de Saint-Cyr, Paris, 1914, reprinted on much better paper 1924, same size page as previous edition, but with the last $30 \mathrm{p}$. omitted. The preface of each print is signed by Bourgeois, and dated "Paris, 1917."

According to Henderson a second edition of the 1889 work was

(8B). o Nouvelles Tables [as in the first edition]. Deuxième édition revue et corrigée, Paris, 1901, with a table of errata in the first edition; preface by Général Bassot, director of the Service Géographique. I have seen

(8C). Nouvelles Tables [as in the first edition]. Deuxième édition revue et corrigée, Paris, 1914. The preface to this second edition is dated Paris, 1914 and is signed by Général Bourgeois, director of the Service Géographique. On p. 236 there is "Errata à la première édition." These were corrected in no. (8A) listed above. And finally, there is

(8D). Nouvelles Tables [as above], Paris, 1927. The errata list has disappeared and p. 236 is blank.

We shall presently list a third work prepared by the Service Géographique de l'Armée.

In Germany during the decade 1885-1895 those dealing with problems of surveying and geodesy felt the great need of a table of logarithms of the trigonometric functions for centesimal divisions of the quadrant, since those of Callet, Hobert and Ideler, and Borda and Delambre, were not easily obtainable. At this juncture appeared at Paris the great 8-place table of the Service Géographique de l'Armée, which would also serve the needs of those desiring a seven, six, or five-place table. Nevertheless WilHelm JoRdan (1842-1899), who was the author of the remarkable three-volume work Handbuch der Vermessungskunde, decided that he would be rendering a service to science by computing a new table,

(9) Logarithmisch-Trigonometrische Tafeln für Neue (Centesimale) Theilung mit sechs Decimalstellen. Stuttgart, 1894 , viii, 420 p. $18.5 \times 26.5 \mathrm{~cm}$.

These tables contain the logarithms of the sine, tangent, cotangent, and cosine (p. 155-414), for $\left[0^{\circ}\left(10^{\prime \prime}\right) 20^{\circ} .10 ; 20^{\circ}\left(1^{\prime}\right) 50^{\circ} ; 6 \mathrm{D}\right]$, and are arranged semiquadrantally. $\mathrm{S}$ and $\mathrm{T}$ values are given for $\left[0^{\circ}\left(1^{\prime}\right) 2^{\circ} .50 ; 6 \mathrm{D}\right]$. On p. 416 are newly calculated $\log \sin x$ and $\log \cos x$, for $x=\left[0^{\circ}\left(1^{\circ}\right) 50^{\circ} ; 15 \mathrm{D}\right]$. Between these key values others were interpolated.

The next three posthumous editions $(9 A)$. o second (1915), (9B). o third (1921), and (9C). fourth (1931), were edited by H. P. O. Eggert. Corrections of errors were made in publishing the second and third editions, but no new errors were found to correct for the fourth.

We shall next refer to the great fundamental tables of the trigonometric functions, both logarithmic and natural, by MARIE HENRI ANDOYer (18621929). These will probably be the basis, direct or indirect, of all other similar tables of value for a century to come. The first is entitled

(10). Nouvelles Tables Trigonométriques Fondamentales (Logarithmes), Paris, Hermann, 1911, $21.8 \times 29 \mathrm{~cm}$.

Table III (p. 9-15) gives the logarithms of sines, cosines, and tangents for each grade to $50^{\circ}$, to $17 \mathrm{D}$, with variations of various orders, Table IV (p. 17-37) 
may be regarded as a table of the logarithms of sine, cosine, and tangent, for $0^{\circ}\left(1 / 6^{a}\right) 50^{\circ}$, to $5 \mathrm{D}$, and other material. The long introduction (p. ix-xxxii) explains the basis of the computation coupled with criticisms of earlier original work, including that of Jordan. The second volume of Andoyer which is also here of interest to us is entitled.

(11). Nouvelles Tables Trigonométriques Fondamentales (Valeurs Naturelles), v. 1, Paris, Hermann, 1915, $24 \times 31.3 \mathrm{~cm}$.

Table II (p. 5-21) contains the values of all six of the natural circular functions and of $g(y)=(200 / \pi y)-\cot y^{o}$ and $h(y)=\csc y^{0}-(200 / \pi y)$, for $y=0^{\circ}\left(1^{\circ}\right) 50^{\circ}$, to $20 \mathrm{D}$; also variations of different orders for the sine, cosine, tangent and secant, and for the functions $g$ and $h$. Table III (p. 23-65) may be regarded as giving the values of all six of the natural trigonometric functions for $0^{\circ}\left(1 / 6^{\circ}\right) 50^{\circ}$, to $17 \mathrm{D}$, and other material.

Turning next to a table which was prepared primarily for use with the Brunsviga calculating machine we have

(12). G. SteINBRENNER, F ünfstellige Trigonometrische Tafeln neuer Teilung (Dezimalteilung des Quadranten) zum Maschinenrechnen nebst einer zehnstelligen Hilfstafel und einer goniom.--trigonom. Formelsammlung. Brunswick, 1914. 174 p. $17.2 \times 25 \mathrm{~cm}$.

E. Reich, Anhang zu G. Steinbrenner: Fünfstellige Tafeln. Hilfstafel für Berechnung der trigonometrischen Richtungskoeffizienten, Brunswick, 1914, $11 \mathrm{p}$.

Table I (p. 5-115) gives the values of the natural sines, cosines, tangents, cotangents, for every $1^{\prime}$ of the quadrant, to $5 \mathrm{D}$, as well as cotangents for $\left[0^{\circ}\left(1^{\prime \prime}\right) 0^{\circ} 15^{\prime}\left(10^{\prime \prime}\right) 3^{o} ; 5 \mathrm{D}\right]$, with p.p.

Table V (p. 134-139) has (a) sines and cosines for each $10^{\prime}$ of the quadrant to $10 \mathrm{D}$; (b) sines, cosines, and tangents for $\left[0^{\prime}\left(10^{\prime \prime}\right) 10^{\prime} ; 10 \mathrm{D}\right]$, all with p.p.

Table VII (p. 142-150) has cotangents for $\left[0^{\prime}\left(1^{\prime \prime}\right) 10^{\prime}\left(10^{\prime \prime}\right) 1^{\circ} 10^{\prime} ; 10 \mathrm{D}\right]$, and sines and tangents for $\left[0^{o}\left(1^{\prime}\right) 1^{o} ; 10 \mathrm{D}\right]$.

We may next refer to a work published in China and written by an engineer on its national railway,

(13). E. A. Slosse, Tables des Valeurs Naturelles des Expressions Trigonométriques. Division Centésimale. Suivies de Tables relatives au tracé de courbes et au calcul des levés trachéométriques, Tientsin, China, Imprimerie de la Mission du Tcheli, S. E., s.d. xxxvi, 425 p. Preface signed "E.A.S., Chengchow, 1923". $12.6 \times 17.8 \mathrm{~cm}$.

The main table I (p. 1-401) gives the values of all of the natural trigonometric functions, the versed sine, and versed cosine, for each half minute, to $6 \mathrm{D}$, for 200 grades. Table III (p. 415-424) contains the values of $\sin ^{2} v$ (haversine $2 v)$, and $\cos ^{2} v$, for $v=\left[50^{\circ}\left(1^{\prime}\right) 150^{\circ} ; 4 \mathrm{D}\right]$. Illustrations show how these functions arise in surveying. We now come to

(14). International Geodetic and Geophysical Union, Association of Geodesy, Special Publication, no. 1, 8 Place Tables of the Natural Values of Sines, Cosines and Tangents according to the Centesimal System, for each Centigrade from 0 to 100 grades, computed under the direction of M. RoussiLHE ...., by M. Brandicourt, . . . followed by 20 place tables of the Natural Values of the six trigonometrical functions according to the centesimal system, for each grade from 0 to 100 grades, taken from the tables of M. Andoyer. Paris, 1925, [144 p.]. $18.5 \times 16.8 \mathrm{~cm}$. There is also a French title page and introduction (p. 1-12).

This 8-place table, with differences, for each centesimal minute, occupies 
p. 25-125, which supplements no.(7), with 8-place logarithms of the circular functions. In spite of the title the tangents $50^{\circ}-100^{\circ}$ can not be read directly from the table. The Anodyer items is taken completely from his work of 1915; see Table II of no. (11) above.

The publication of these tables was first suggested at the International Geodetic and Geophysical Union held at Rome in 1922. At first the tables were to give 7 decimals, but in a conference of 1924 at Madrid, it was finally resolved to publish 8 decimal. With such tables it was estimated that an accuracy of 1 millimeter in 50 kilometers would be obtained.

There are the following errors corrected by hand in the Brown University copy of this edition:

In D-column for sinus $7 \circ$ bet. 02 and 03 , for 17612 read 15612.

In D-column for cosinus $7^{\circ}$ bet. 06 and 07 , for 1339 read 1739 .

In $\tan 14^{\circ} .65$, for 0.23426170 read 0.23427170 .

Other places where the type is blurred and a number can not be read are: $\tan 20.66=0.04180751$; $\cos 30^{\circ} .50=0.88741345 ; \sin 43^{\circ} .15=0.62707976 ; \mathrm{D}$, after $\cos 477^{\circ} .34,10634$.

These are corrected in the

(14A). "New revised edition" (Paris, 1933) which has the heading "International Geodetic and Geophysical Union Association of Geodesy." The number of pages is the same. The table of sines is based on the 15-place table of Callet, no. (5), and the table of tangents on the 15-place table of Andoyer, 1916.

Another work of importance is that of

(15). Johann Theodor Peters (1869- ), Sechstellige trigonometrische Tafel für jede Minute des in hundert Grade geteilten Quadranten. Berlin, Gebr. Wichmann, 1930 . vi, 170 p. $17 \times 25.8 \mathrm{~cm}$.

Table I gives (p. 1-44) the values of cosecant and cotangent for $0^{\circ}\left(10^{\prime \prime}\right) 10^{\circ}$, to 5 or $6 S$, with p.p.; also the values of $w^{0} \cdot \cot w$ and $w^{0} \cdot \csc w$ for $w=0^{0} .000$ $-2^{\sigma} .000$; whence, for example, csc $w=w \csc w / w$. In Table II (p. 45-145) the values of all of the circular functions are given for every centesimal minute, with p.p.

In October $1938 \mathrm{Mr}$. Peters reported to Mr. Comrie that he had (16). seven and (17). eight-place tables of the trigonometric functions for every $0.001^{\circ}$, and a (18). ten-place table for every $0.01^{\circ}$. Thus tables with centesimal divi$\operatorname{sion}^{7}$ of the quadrant are regarded as of importance even in recent times in Germany, especially for dealing with problems of surveying and ballistics.

A great work of science in which the centesimal division of the quadrant and day is used, is Laplace's Mécanique Céléste (5 v., Paris, 1799-1825).

C. Mils. The third work prepared by the French Service Géographique de l'Armée was entitled

(19). Tables de Logarithmes a cinq Décimales pour les Nombres de 1 d 12000 et pour les Lignes Trigonométriques dans le Système de la Division de la Circonférence en 64000 parties égales (dixième du millième de l'Artillerie). Paris, Imprimerie Nationale, 1916 , [232 p.]. $17 \times 25.7 \mathrm{~cm}$.

The first 64 pages of logarithms of numbers are the same as in the other fiveplace tables of the Service Géographique. Then follows a five-place table, with p.p., of the logarithms of each of the six trigonometric functions for every sixtyfour thousandth of the circumference. $2 \pi(10,000) \approx 62831.8$, which may be rounded of to 64000 . I am unfamiliar with any similar extensive printed table 
of this "artillery unit" or mil, $1 / 16000$ of a quadrant, or $20.25^{\prime \prime} ; 1^{o}=160$ mils. On the first of the 80 double pages of the table we find the values for the ranges $0(1) 100,15900$ (1) 16100,31900 (1)32100, 47900(1)48100, 639000-64000. High accuracy for this peculiar table may be assumed since it was prepared by Henri Andoyer. It supplied needs of the French artillery units in the last great world war. On p. 229 there is a table of $\log (\sin x / x)$, and of $\log (\tan x / x)$, for $x=0.0000(.0004) 0.0600$.

On punched cards of the International Business Machines Corporation are many sets of cards of mathematical tables. Among the sets at Princeton UNIVERSITY is one of (20). 8000 cards of a table of the 6 natural trigonometric functions as well as of $\frac{1}{2}$ tangent and $\frac{1}{2}$ cotangent, for every tenth of a mil, to $5 \mathrm{D}$, throughout the quadrant. About a year ago this table was being expanded to include the logarithms of the sine, cosine, and tangent, for the same range.

A reference may be given to R. S. Burington, "The mil as an angular unit and its importance to the army," Amer. Math. Mo., v. 48, 1941, p. 188-189.

D1. Gones. The type of trigonometric tables here to be considered is chiefly represented by a large work of the Mexican engineer and geographer, Joaquin de Mendizábal Tamborrel (1856-1926). In his choice of the circumferences as the unit (a gone) he followed Villarceau, ${ }^{8}$ and divided this into a million parts. The terms decigone, centigone, miligone, . . . microgone were applied to angles $1 / 10,1 / 100,1 / 1000, \cdots, 1 / 1000000$ of a gone; thus 1 microgone $=1^{\prime \prime} .296$. 1 gone $=100 \mathrm{cir}=1000000$ microgones $=400^{\circ}=360^{\circ}$. The table in question is

(21). J. DE MendizÁBAL TAMBorRel, Tables des Logarithmes à huit Décimales des Nombres de 1 da 125000 et des fonctions goniométriques sinus tangente, cosinus et cotangente de centimiligone en centimiligone et de microgone en microgone pour les 25000 premiers microgones et avec sept décimales pour tous les autres microgones. Paris, 1891. [ix, 307 p.], $26.7 \times 36.5 \mathrm{~cm}$.

At the foot of pages 1-59 of logarithms of numbers, are given the values of $\mathrm{S}$ and $\mathrm{T}$ for the first 12500 microgones, i.e., to $4^{\circ} 30^{\prime}$, to $8 \mathrm{D}$. Beginning with page 60 each page corresponds to a miligone; the logarithms of sines and tangents are on the left-hand pages and the logarithms of cosines and cotangents, for the same range, on the opposite right-hand pages. The values are given in (a) a single entry table for [0(10) $125000 ; 8 \mathrm{D}]$; (b) a double-entry table for every microgone, 0 to 25000 , to $8 \mathrm{D} ; 25000$ to 125000 , to $7 \mathrm{D}$. P.p. are given from 12000 on. Suitable headings at the top and bottom of each page lead to results for any number of microgones in the circumference. These remarkable tables were mainly the result of original 10-place calculations completed in 1888 . Only the logarithms of the numbers 1-1200 were taken from Callet's Table and those of the numbers 100,000 to 108,000 from Schrön's. (The statement of the Fortschritte review in this connection is incorrect.) They were checked against the manuscript (3). Tables $d u$ Cadastre and the printed volume (1891) of the Service Géographique de l'Armée. The following table published by the same author a few years later is hardly worth a reference:

(22). "Tables numériques d'après la division décimale de la circonférence et du jour," Sociedad Científica "Antonio Alzate," Memorias, Mexico, v. 13, nos. 7-8, 1903, math. suppl., 12 p. $16 \times 21.7 \mathrm{~cm}$.

Table II (p. 4-9) gives the values of the circular and hyperbolic functions ( $\sin$ or tanh, csc or coth, tan or sinh, cot or csch, sec or cosh, cos or sech) to $4 \mathrm{D}$, for the range $0(.25) 250$, each unit being 1000 microgones. Table III (p. 
9-12) contains the logarithms of the same functions for the same range. Compare RMT 89, Vassal.

D2. Cirs.-We have noted (p. 13) that (23). BRIGgs in his Trigonometria Britannica gave a table (p. 43) of sines to 19D for all angles obtained by dividing the quadrant into 144 equal parts. It is not appropriate here to discuss why or how such a table illustrates his discussion, and the same remark applies to what now follows. For fuller information the curious reader may either turn to the work itself or to the detailed description by Delambre. ${ }^{9}$ Briggs remarks that some zealous amateurs have desired a new division of the circle, which is centisimal, so that the quadrant is divided into 25 units, or cirs, or centigones. To facilitate the preparation of a table of natural sines for thousandths of such a unit, he gives a curious table to $16 \mathrm{D}$ for each 0.625 of a unit in the quadrant, the first four and last four of the 40 entries being as follows:

\begin{tabular}{|c|c|c|}
\hline $\begin{array}{l}0.625 \\
1.250 \\
1.875 \\
2.500\end{array}$ & $\begin{array}{l}2^{\circ} 15^{\prime} \\
430 \\
645 \\
900\end{array}$ & $\begin{array}{l}.0392598157590686 \\
.078459095727845 \quad 1 \\
.117537397457837 \\
.1564344650402308\end{array}$ \\
\hline $\begin{array}{l}23.125 \\
23.750 \\
24.375 \\
25.000\end{array}$ & $\begin{array}{ll}83 & 15 \\
85 & 30 \\
87 & 45 \\
90 & 00\end{array}$ & $\begin{array}{r}.993068456954926 \\
.9969173337331280 \\
.999229036240722 \\
1.000000000000000\end{array}$ \\
\hline
\end{tabular}

Briggs notes that this table may then be extended to each 0.125 of a unit, and then to each 0.025, each 0.005, and to each 0.001. The methods of Briggs were also used by Sang (see R. So. Edinb., Proc., v. 9, p. 345-347).

A later table with arguments in this unit is the quite unimportant one of

(24). Joseph Charles François Rey-Pailhade (1850- ), "Table des logarithmes à quatres décimals de toutes les lignes trigonométriques dans la division décimale du cercle entier," Société Géographique de Toulouse, Bull., v. 19,1900 , p. $94-103.13 .5 \times 21.4 \mathrm{~cm}$. Also issued as a pamphlet, Paris, 1900, $12 \mathrm{p}$.

To this author is due the name Cir $(1 / 100$ of the circumference $=10$ miligones). The table is for each of the circular functions for every tenth of a cir in the quadrant; and also for $\log (\sin x / x)$ and $\log (\tan x / x)$ for $x=0.0(0.1) 2.5$. Since 100 cirs and a gone are identical, all of the entries (except those for log $\operatorname{cosec}$ and $\log \mathrm{sec}$ ) are given much more extensively in no. (21).

E. Time. In astronomy right ascension, hour angle, and other related quantities, are measured in hours, minutes, and seconds of time. To use with that, tables of trigonometric functions in sexagesimal arguments, called for the employment of conversion relations ( $\operatorname{such}$ as $6^{\mathrm{h}}=90^{\circ}, 1^{\mathrm{h}}=15^{\circ}, 4^{\mathrm{m}}=1^{\circ}, 1^{\mathrm{m}}=15^{\prime}$, $\left.1^{s}=15^{\prime \prime}\right)$, a source of frequent error. Hence a number of tables of circular functions with time as argument have been compiled or computed during the past century. We list a few of the logarithmic tables, 5D-7D, and tables of natural functions, 5D-10D. The poor first table came from an observatory, namely:

(25). George Biddell Airy (1801-1892), Appendix to the Greenwich Observations, 1837: containing no. III, Logarithms of Sines and Cosines to Time, for every ten Seconds through the twenty four hours. Computed under the direction ..., printed first in 1838: reprinted, London, 1864 , xliv p. $24.5 \times 31.7 \mathrm{~cm}$.

Two large folio pages are devoted to each of the 24 hours of the day; on one page is $\log \sin$ for each $10^{\mathrm{s}}$ of $60^{\mathrm{m}}$, to $5 \mathrm{D}$, and on the opposite page is log cos. It is thus an "eight-fold repetition of one table" (De Morgan). The phrase 
"computed under the direction" is applied to a mere rearrangement of some five-place table. We may next note the title of

(26). Robert ShORTREde (1800-1868), Logarithmic Tables, to Seven Places of Decimals containing . . . Logarithmic Sines and Tangents to every second of the Circle with Arguments in Space and Time. Edinburgh, 1844. iv, 597 p. $17.3 \times 24.5 \mathrm{~cm}$. (26A). Second ed., 1849; (26B). another ed., 1848; (26C). posthumous and rev. ed. London, 1873.

This notable table was the most complete second canon in existence at the time of its publication. Beside every sexagesimal second of argument is given the corresponding time argument. Of two earlier second canons was the posthumous work of Michael Taylor (1756-1789) Tables of Logarithms of all Numbers, from 1 to 101000 and of the Sines and Tangents to every Second of the Quadrant. London, 1792. This work and Shortrede's were the basis of

(27). NORBERT HERz (1858- ), Siebenstellige Logarithmen der trigonometrischen Functionen filr jede Zeitsecunde, zum astronomischen Gebrauche herausgegeben. Leipzig, 1885 . iv, 182 p. $16.4 \times 24.1 \mathrm{~cm}$. Each page is devoted to a minute of time and the logarithms of sines, tangents, cotangents, cosines, to $6 \mathrm{D}$, with differences and p.p. $S$ and $T$ are given for $0^{\mathrm{h}} 0^{\mathrm{m}}$ to $0^{\mathrm{h}} 20^{\mathrm{m}}$. In the preface are noted two errors in Taylor's table, and one in Shortrede's, not previously listed. We turn back chronologically to

(28). John Caulfield Hannyngton (1807-1885), Haversines Natural and Logarithmic used in Computing Lunar Distances for the Nautical Almanac, London, 1876.327 p. $20.2 \times 32.1 \mathrm{~cm}$.

Versine $t=1-\cos t=2 \sin ^{2}(t / 2)$; haversine $t=\sin ^{2}(t / 2)$. The first table (p. 2-145) is for twelve hours and gives log haversine for every time second, $5^{\mathrm{m}}$ on each page, to 5D, with differences and p.p. Corresponding to each time second, the angular argument is also given. In the table of natural haversines ( $p$. 148-327) the argument is for each $10^{\prime \prime}$ (with corresponding time arguments) from $0^{\circ}$ to $180^{\circ}$ (12 hours), to $7 \mathrm{D}$, with p.p. An admirably printed volume. In chronological order we may next list

(29). Friedrich Bidschof (1864-1915) and ARthur Vital, Fünfstellige mathematische und astronomische Tafeln. Zum Gebrauche für Mathematiker, Astronomen, Geographen, und Seeleute zusammengestellt und mit Formelsammlung versehen. Stereotype-Ausgabe. Vienna and Leipzig, 1905, xviii, 219 p. $16.7 \times 25.8 \mathrm{~cm}$.

Table 8 (p. 58-115) is a table of the 6 circular functions for every $1^{\prime}$, to $5 \mathrm{D}$, with differences and with corresponding time arguments, each $4^{\mathrm{s}}$. Table 11 (p. 104-115) has $\log$ haversine $t$ for $t=\left[0^{\mathrm{h}}\left(5^{\mathrm{s}}\right) 12^{\mathrm{h}} ; 5 \mathrm{~S}\right]$. There are many other navigation tables with time as argument, but reference will be given to only one, which has passed through many editions, 1830-1910, namely:

(30). James InMan (1776-1859), Nautical Tables designed for the Use of British Seamen, new ed., London, 1858.

The logarithms of all six of the trigonometric functions, as well as of haversines, are given for every second of time, to 6D, p.[37]-[216], and 217-275. And now one more volume in the remarkable series by

(31). J. T. Peters, Fünfstellige Logarithmentafel der trigonometrischen Funktionen für jede Zeitsekunde des Quadranten, Berlin, 1912. iv, 83 p. 18.8 $\times 26.6 \mathrm{~cm}$.

This is simply a table of the logarithms of sines, tangents, cotangents, cosines, for each time second, to $5 \mathrm{D}$. On each page are the values for $2^{\mathrm{m}}$, with p.p. 
throughout the table, but no differences. In another table we find log sin and $\log \tan$ for $0^{\mathrm{h}} 0^{\mathrm{m}}$ to $0^{\mathrm{h}} 8^{\mathrm{m}}$, and of $\log \cos$ and $\log \cot$ for $5^{\mathrm{h}} 52^{\mathrm{m}}$ to $6^{\mathrm{h}} 0^{\mathrm{m}}$, for each tenth of a time second. At least as long ago as 1935 Peters had also prepared (32) a six-place table of the natural trigonometric functions for every second of time.

Further tables of natural trigonometric functions are those computed by

(33). [D, Q].-W. Dieckvoss and H. Kox, Sammlung von Hilfstafeln der Hamburger Sternwarte in Bergedorf. J. Tang $0^{\mathrm{h}} 0^{\mathrm{m}}-$ Tang $1^{\mathrm{h}} 0^{\mathrm{m}}$, and $K$. cos $0^{\mathrm{h}} 0^{\mathrm{m}}-\cos 1^{\mathrm{h}} 0^{\mathrm{m}}, 1935.64$ p. and 64 p. $19.2 \times 26.3 \mathrm{~cm}$.

Table $\mathrm{J}$ is for $\left[0^{\mathrm{h}} 0^{\mathrm{m}}\left(0.1^{\mathrm{s}}\right) 1^{\mathrm{h}} 0^{\mathrm{m}} ; 7 \mathrm{D}\right]$, with p.p., and Table $\mathrm{K}$ for the same range and extent. These were the first tables of the natural functions to $7 \mathrm{D}$ (if one excludes Hannyngton's Haversine table), and were published for the specific purpose of astrographic plate reductions.

We began this section by listing a very unworthy publication, no. (25), of the Greenwich Observatory, but approach the section's conclusion with an account of a high-class work of importance prepared by H. M. Nautical Almanac Office. This is

(34). [D, Q].--[L. J. ComRIE], Seven-Figure Trigonometrical Tables for every Second of Time. London, His Majesty's Stationery Office, 1939. 101 p. $17.3 \times 26.2 \mathrm{~cm}$.

In December 1938 the Astronomer Royal wrote as follows: "The preparation of these tables was commenced and completed under the direction of Dr. L. J. Comrie, late Superintendent, about twelve years ago, but it was not until 1932 that the final copy for the main table was prepared for the printer and approval for publication obtained. During this period manuscript tables, or rather tables printed by the adding machine that makes the final copy, have been in continual use in the Nautical Almanac Office; the table of tangents has proved invaluable in the formation of the right ascensions of Sun, Moon and planets."

The tables give the seven-figure natural values of the sine, cosine, tangent, and cotangent (p. 11-101) for every second of time in the quadrant, arranged semiquadrantally, with an auxiliary table (p. 7-10) of the function $x^{8} \cot x^{s}$, to $3 \mathrm{D}$ or $8 \mathrm{~S}$, for every second to $30^{\mathrm{m}}$. The tables are intended for use with a calculating machine, and certain methods of direct and inverse interpolation can be used. The original 10D values were calculated with the aid of Andoyer's Nouvelles Tables Trigonométrique Fondamentales (Valeurs Naturelles) (v. 1-2, 1915-16), and Brandenburg's Siebenstellige Trigonometrische Tafel (second ed., 1931). In proof-reading checking was also done with no. (31).

In 1898 Henri de Sarrauton ${ }^{10}$ proposed that the circumference be divided into 240 degrees, each hour being then divided into $10^{\mathrm{d}}$, and each degree into $10^{\mathrm{m}}$, each minute into 10 seconds, each second into thirds, etc. We are informed that M. Lebesgue, "eminent mathematician of Brussels," and his collaborator, M. Maurice Méry, actually calculated (35). Tables des Fonctions Circulaires de la Division en $240^{\mathrm{d}}$. I have not found that this ms. was ever published, nor can I identify M. Lebesgue.

Except for nos. (8), and (8C) in Library of Congress, and for certain items marked with "o," all printed tables mentioned in this article are (either in their original, filmed, or photostat form), in the library of Brown University. Originals of nos. (13), (25), and (29) are in the library of Harvard University, and of no. (33) in the U. S. Naval Observatory. I used a copy of no. (12) be- 
longing to Mr. F. W. Hoffman of Pawtucket, R. I.; it does not appear to be in any of the larger libraries of America.

R. C. A.

1 S. Günther, Studien zur Geschichte der mathematischen und physikalischen Geographie. IV. Analyse einiger kosmographischer Codices der Münchener Hof- und Staatsbibliothek, Halle, a/S., 1878, p. 249; codex p. 174 $176^{\mathrm{r}}$ : "Et notandum quod in praesenti tabula quilibet gradus et hora dividitur in 100 minuta, et quodlibet minutum in 100 secunda et sic de aliis." See $\mathbf{M}$. Cantor, Vorlesungen über Geschichte der Mathematik, v. 2, 2nd ed., Leipzig, 1900, p. 185. Since the destruction of the library in March 1943, the codex may well be no longer in existence.

2 Trigonometria Britannica sive Doctrina Triangvlorvm Libri Dvo, Gouda, 1633. vi p.; Trigon. Brit, lib. I, p. 1-60; Trig. Brit., lib. II, p. 61-110; table, 264 p. It was only the second book, on spherical trigonometry (50 p.) which was written by Gellibrand; all the rest was by Briggs; see Gellibrand's prefatory greetings to students of mathematics. Here, as usual, Delambre ${ }^{9}$ is right. Unfortunately I first accepted as correct the statement of Glaisher (Report, p. 65) "The trigonometry is by Gellibrand." Hence the statements in $M T A C$, p. 10 (1. 18), 13 (1. 8), 26 (1. 1), should be modified accordingly, and the name Briggs be substituted for Gellibrand in the footnote on p. 13. Gellibrand tells us that Briggs' "Canon of Sines" was his first work, prepared "thirty years more or less" before, and that finally, tired out by the importunities of his friends to have it published, he decided to prepare it for the press, but had completed only the first book of the introduction at the time of his death. This statement suggests that Briggs may have computed the tables of natural sines, tangents and secants about 1600 , and added the much less accurate logarithms of sines and tangents (see Delambre ${ }^{9}$ and (10). Andoyer) perhaps about 1620, a few years after logarithms were first conceived. The interested reader will not overlook the tribute to Briggs in Delambre's "Rapport."

3 R. Mehmke, "Bericht über die Winkelteilung im Namen der Tafelcommission der Deutschen Mathematiker-Vereinigung," D. M. V., Jahresb., v. 8, 1900, p. 139-158; see especially p. 145-146. Here are many valuable details supplementing the present article.

"Fuller information concerning matters here discussed may be found in the following sources: Riche de Prony, (a) "Notice sur les grandes tables logarithmiques et trigonométriques," and (b) "Éclaircissemens sur un point de l'histoire des tables trigonométriques," Mémoires de l'Institut National des Sciences et Arts. Sciences Mathématiques et Physiques, v. 5, Paris, 1803, p. 49-55, and 67-93.

J. B. J. Delambre, "Rapport sur les grandes tables trigonométriques décimales du Cadastre," idem, p. 56-66.

P. A. F. Lefort, (a) "Description des grandes tables logarithmiques et trigonométriques, calculées au Bureau du Cadastre sous la direction de Prony et exposition des méthodes et procédés mis en usage pour leurs construction," Paris, Observatoire, Annales, v. 4, 1858, Supplément, p. [123]-[150]; (b) "Note sur les deux exemplaires manuscrits des grandes tables logarithmiques et trigonométriques calculees au Bureau du Cadastre," Institut de France, Acad. d. Sc., Comptes Rendus, v. 46, 1858, p. 994-999. See also Nouv. Ann. d. Math., v. 14, 1855, p. (14)-(17); and DeMorgan's article on Prony in Penny Cyclopadia, v. 19, 1841.

6. W. L. Glaisher, "On logarithmic tables," R. Astr. So., Mo. Notices, v. 33, 1873, p. 455 footnote.

- See "List of logarithmic, trigonometrical, and astronomical calculations, in manuscript, by Edward Sang," p. 44-47 of E. M. Horsburgh, Modern Instruments and Methods of Calculation, London and Edinburgh, 1914. See also R. So. Edinb., Proc., v. 9, 1878, E. Sang, "On the construction of the canon of sines, for the decimal division of the quadrant," p. 343-349;. "On the precautions to be taken in recording and using the records of original computations," p. 349-352. V. 12,1884 , "On the construction of the canon of logarithmic sines," p. 601-619; v. 16, 1890, "Notice of fundamental tables in trigonometry and astronomy, arranged according to the decimal division of the quadrant," p. 249-256. See also Proc., v. 28, 1908, p. 183-196.

7 For grades, minutes and seconds we have used the notation $\mathrm{g}$, ,". Fourteen other varieties of notations are exhibited by $\mathrm{Mehmke}^{3}$ (p. 153). None of these are listed in Cajori's History of Mathematical Notations (1928-29).

${ }^{8}$ Institut de France, Acad. d. Sci., Comptes Rendus, v. 70, 1870, p. 1233-1236, 1390; and v. 71,1870 , p. 362-368. The astronomer Antoine Joseph Yvon Villarceau (1813-1883) to whom reference is here made, was the discoverer of the third series of circles on the torus ("Villarceau circles"; see "Theorème sur la tore," Nouv. Ann. Math., v. 7, 1848, p. 345 ff. for an analytic proof, and F. G. M., Exercises de Géométrie Descriptive, fourth ed., Tours and Paris, 1909, p. 573 ff. for a geometric proof.)

$\mathrm{J}$. B. J. Delambre, Histoire de l'Astronomie Moderne, v. 2, Paris, 1821, p. 76-85, 393-420.

${ }_{10}$ Institut de France, Acad. d. Sci., Comptes Rendus, v. 126, 1898, p. 192-194. We are told that the decimal hour proposal was made in 1895 and that already decimal watches and decimal chronographs were available. 